\author{
Nicholas Coureas \\ http://orcid.org/0000-0001-8903-8459 \\ Cyprus Research Centre in Nicosia \\ ncoureas@hotmail.com \\ DOI: 10.35765/pk.2021.3504.05
}

\title{
The Greek Church in Latin and Venetian Cyprus
}

$$
1191-1570
$$

\section{AB STRACT}

The Greek Church faced considerable problems following the Latin Conquest of Cyprus and the establishment of the Lusignan dynasty. Much of its property was impounded by the new Latin rulers, in the 1220s its bishoprics were reduced to four, with each bishop subject to a Latin diocesan. Under the provisions of the Bulla Cypria of 1260 it accepted papal primacy and ceased to have its own archbishop following the death of Germanos. Limits were placed on the numbers of monks in Greek monasteries and the refusal of Greek monks to accept the validity of Latin unleavened communion bread resulted in the martyrdom of 13 of them in 1231. Despite this, however, the Greek Church overcame these challenges and even strengthened its position in the later Lusignan and Venetian periods. Several reasons explain its ability to survive and maintain the allegiance of most of the population. The small number of Latins on Cyprus, concentrated mainly in the towns of Nicosia and Famagusta, made them fear absorption into the far more numerous Greeks and so disposed to tolerate a Greek Uniate Church that formally accepted papal primacy. The great distance separating Cyprus from Rome and Avignon together with increasing absenteeism among the Latin clergy from the later fourteenth century onwards made it impossible to enforce papal directives. The growing Ottoman threat from the late fifteenth century onwards likewise made the Venetian authorities on Cyprus reluctant to implement papal rulings that would anger the Greek majority. In addition, the Greek Church of Cyprus maintained contact with the Greek patriarchates of Constantinople, Antioch and Alexandria, all outside the areas under Latin rule, and so was not isolated from the Orthodox Christians subject to the patriarch of Constantinople.

KEYWORD : Greeks, Latins, Lusignans, Venetians, monasteries, Bulla Cypria, papacy, clergy 


\section{STRESZCZENIE}

Kościół grecki na Cyprze łacińskim i weneckim 1191-1570

Po łacińskim podboju Cypru i ustanowieniu dynastii Lusignanów Kościół grecki stanął w obliczu poważnych problemów. Duża część jego majątku została skonfiskowana przez nowych łacińskich władców, w latach 20. XII w. liczba jego biskupstw została zredukowana do czterech, a każde z nich podlegało łacińskiemu biskupowi diecezjalnemu. Na mocy postanowień Bulli Cypriańskiej z 1260 r. diecezje przyjęły prymat papieski, a po śmierci Germanosa przestały mieć własnego arcybiskupa. Ograniczono liczbę mnichów w greckich klasztorach, a odmowa przyjęcia przez nich ważności łacińskiego niekwaszonego pieczywa eucharystycznego doprowadziła do męczeńskiej śmierci trzynastu z nich w 1231 r. Mimo to Kościół grecki przezwyciężył te trudności, a nawet wzmocnił swoją pozycję w późniejszym okresie panowania Lusignanów i Wenecjan. W tekście wyjaśniono kilka powodów tej zdolności do przetrwania i utrzymania lojalności większości mieszkańców. Niewielka liczba łacinników na Cyprze, skupionych głównie w miastach Nikozja i Famagusta, sprawiała, że obawiali się oni wchłonięcia przez znacznie liczniejszych Greków i dlatego byli skłonni tolerować grecki Kościół unicki, który formalnie akceptował prymat papieski. Ogromna odległość dzieląca Cypr od Rzymu i Awinionu, wraz z rosnącą absencją wśród łacińskiego kleru od końca XIV w., uniemożliwiała egzekwowanie papieskich dyrektyw. Rosnące zagrożenie osmańskie od końca XV w. również sprawiło, że władze weneckie na Cyprze niechętnie wdrażały papieskie nakazy, które mogłyby rozgniewać grecką większość. Ponadto, Kościół grecki na Cyprze utrzymywał kontakt z greckimi patriarchatami Konstantynopola, Antiochii i Aleksandrii, które znajdowały się poza obszarami pod panowaniem Kościoła łacińskiego, a więc nie był odizolowany od prawosławnych chrześcijan podlegających patriarsze Konstantynopola.

SŁOWA KLUCZE: Grecy, łacinnicy, Lusignanowie, Wenecjanie, klasztory, Bulla Cypria, papiestwo, duchowieństwo

\section{The early to middle Lusignan period (1191-1373)}

The Greek Church of Cyprus, spiritually subject to the Patriarchate of Constantinople and enjoying administrative autonomy - or autocephaly - since the Council of Ephesus of 431 (Englezakis, 1995, I, pp. 29-40), underwent a more radical change as a result of the Latin conquest in 1191 than at any other time before or since in its long history. Here, these changes, their effects, and how the Greek Church reacted and adapted to them will be examined, with special emphasis on the period of Venetian rule. 
Around the Third Crusade, and following the conquest of Cyprus in 1191 by the forces of King Richard I of England, the island was sold twice, first to the Order of the Templars, who returned it after a bloodily suppressed Greek revolt in Nicosia, and then to Guy de Lusignan, the dispossessed king of Jerusalem, who founded a Latin Roman Catholic dynasty that ruled Cyprus until 1473 (Edbury, 1991, 1994², pp. 1-12). As Roman Catholics, the Latin kings, nobles and merchants settling in Cyprus in the wake of the conquest could not have their spiritual needs catered to by a Greek Church, considered schismatic by the papacy. Therefore, a Latin Church of Cyprus, consisting of one archdiocese of Nicosia and three suffragan dioceses of Paphos, Limassol and Famagusta, was founded in 1196 under Pope Celestine III, with the declared aim of bringing the Greek Church under the jurisdiction of the papacy (Coureas, 1997, pp. 3-6; Schabel, 2010, vol. 1, a-1 to a-3).

Until the Limassol and Famagusta agreements of 1220 and 1222, the latter of which the papacy confirmed in 1223, intervention in the affairs of the Greek Church was minimal. Nonetheless, some of the 14 Greek bishoprics existing in Cyprus prior to 1191 were amalgamated, probably for economic reasons, given that the end of Byzantine rule over Cyprus had resulted in the ending of Greek churches and monasteries' patronage from the Byzantine emperors and nobility, who had largely fled the island after the conquest, although some Greek landowners remained. Neophytos the Recluse, who founded a monastery in the hills outside Paphos at the close of the twelfth century and witnessed the Latin Conquest, bewailed its effects but he acknowledged that the Latins had not harmed his monastery and adopted a cautious attitude towards them instead (Coureas, 1997, pp. 252-259). Nonetheless, the extant Greek monastic foundation rules of the period, those of Neilos for the monastery of Makhairas and of Neophytos the Recluse for the Engleistra monastery did set limits on the numbers of candidates entering the monastery to become monks, thereby presaging the limits on their entry according to the terms of the 1220 and 1222 agreements (Coureas, 2003, pp. 50-51, chapters 164 [Neilos] and 9 [Neophytos]).

These agreements came into being after the Fourth Crusade of 1204, by which time Constantinople, most of mainland Greece, Crete and many Aegean islands had come under Latin rule. Under Pope Honorius III (1216-1227), the papacy formulated a more interventionist policy towards the Greek Churches in Latin ruled territories with a view to implementing their subjection to papal jurisdiction. In Cyprus, this resulted in the conclusion of the 1220 and 1222 agreements between the Latin crown and nobility on the one hand and the Latin secular Church and the Roman Catholic military orders on the other, as confirmed by Pope Honorius III 
in January 1223. Despite the fact that the Greek Church was not a party to either agreement, some of the provisions affected it directly. These were the ones officially reducing the number of Greek bishops to four, with each of the remaining bishops to be resident in one of the four Latin dioceses and to be subordinate to the Latin diocesan. This represented a retreat from the Pope Honorius' initial position that there should only be Latin bishops on Cyprus, but it also meant that henceforth, the Greek bishops would have no territorial jurisdiction, being placed directly under their Latin diocesans, and so they would cease to be bishops pleno iure (Coureas, 1997, pp. 259-274; Schabel, 2010, vol. 1, c-47; Coureas \& Schabel, 1997, nos. 82-84).

In a wider context, the position of Greek bishops in Cyprus from now on corresponded roughly to those of the Greek presules of Southern Italy and Sicily, another area where a Latin Church had been founded among predominantly Greek-rite Christians (Herde, 2002, pp. 240-251). The existence of a Greek archbishop of Cyprus was tacitly ignored in these agreements. The numbers of Greeks entering the Greek secular clergy and the monasteries was also limited by these agreements. The reason for this was that many of them were serfs and the numerical limits aimed at preventing too many serfs from leaving the lands of their Latin feudal lords, especially since the Greek deacons and priests were relieved by the same agreements from having to perform manual labour. Greek churches and land owning monasteries, as well as Greek and Melkite Syrian secular landowners, also had to pay tithes to the Latin Church, although not on properties they had owned prior to 1214, the date of the Fourth Lateran Council at which the Greeks' obligation to pay such tithes and under what circumstances was defined (Coureas \& Schabel, 1997, nos. 82-84; Schabel, 2010, vol. 1, c-47). Greek monks, however, apparently continued to have servile obligations. The monks of Neangomi, a Greek monastery under royal protection granted to an officer of the crown on a lifetime basis in the late thirteenth or early fourteenth century, were exempted from such obligations under the terms of this grant, proof that up until then they had been performing them (Beihammer, 2007, no. 45).

These agreements and their implementation caused a split in the ranks of the Greek clergy, between those desiring an accommodation with the Latins and those advocating resistance. Greek monks were prominent among the latter, even if the resistance advocated was non-violent, and focused on condemning the perceived dogmatical errors of the Latins, especially over their use of unleavened bread (Kyriacou, 2018, pp. 8-12 and 233-237). When the Dominican friar Andrew engaged in a debate with some of them in the monastery of Kantariotissa near Kantara, over the validity of the unleavened communion bread used by the Latins, the rejection of his viewpoint by the 
13 monks there, who included refugee monks from the monastery of Kalon Oros in southern Anatolia, caused him to have them arrested. They were taken to Nicosia, stopping overnight at the Greek monastery of St George of Mangana, the wealthiest Greek monastery in Cyprus, near the capital. They were gaoled in Nicosia for several years as their persisted in their position, with one of them dying in captivity. The matter was finally brought to the pope, who instructed the Latin archbishop to hand them over to the secular arm if they remained obdurate. This done, the remaining 12 monks were burnt at the stake in 1231, and their bones were mixed with those of unclean animals to prevent their retention as relics. This martyrdom, unique in the Greek lands coming under Latin rule, also occurred during a period of civil war and a royal minority, for the Latin rulers and nobility of Cyprus in general sought to prevent such inter-confessional bloodshed. For the Latin clergy however, the refusal of their Greek counterparts to accept the validity of unleavened bread made them heretics, and not just on Cyprus. According to the life of Luke, a Greek bishop of Isola Capo Rizzuto in the Norman kingdom of Sicily, the Latins attempted to burn him alive in around 1100 when he denied the validity of unleavened bread, comparing the Latins to Pharisees, but he survived miraculously (Coureas, 1997, pp. 281-285; Schabel, 2010, pp. III, 2-21).

Not all the Greek clergy counselled uncompromising resistance. When a delegation of Greek prelates visited Germanos, the ecumenical patriarch of Constantinople, then in exile in Nicaea, they were initially advised to accept some of the Latin demands, although the unexpected intrusion of irate Greek refugees from Latin Constantinople to this meeting stiffened the patriarch's resolve against the Latins. In two letters of 1223 and 1229, Patriarch Germanos advised the Greeks and Syrians of Cyprus to obey the Latins superficially, but to avoid canonical obedience to them and keep away from those Greeks who had done so. The remonstrations of the Greek prelates of Cyprus indicated that some of the island's Greek bishops had accepted papal jurisdiction and primacy, excommunicating those refusing to submit. Furthermore, after the burning of the 13 monks mentioned above, the Greek archbishop of Cyprus Neophytos implored the Byzantine Emperor John Vatatzes to cease urging confrontation with the Latins, while also pointing out that the monks had gone to their deaths willingly and after heaping abuse on their captors (Nerantzi-Varmazi, 1996, pp. 121-130; Coureas, 1997, pp. 283-287). Under Pope Innocent IV, a more conciliatory policy towards the Greek clergy was followed, although not as regarded making Greeks conform to Latin liturgical usages where their own customs were divergent. It was during his pontificate that Greek converts to the Latin rite are first recorded, in regulations that the Latin Church of Nicosia promulgated on Palm Sunday 
1251, concerning their mass attendance in the Latin cathedral of St Sophia and their confession to Latin priests (Schabel, 2001, pp. 154-157; Coureas, 1997, pp. 287-296; Kyriacou, 2018, p. 13). Nevertheless, any plans the pope may have had about creating parallel Latin and Greek Episcopal hierarchies, with both being directly subordinate to Rome, were fervently resisted by Hugh of Fagiano, a Praemonstatensian monk who became Latin archbishop of Nicosia in 1251. Pope Innocent's death in 1254 and the succession of the more conservative Pope Alexander IV resulted in the resolution of the dispute between the Latin and Greek clergy of Cyprus by the Bulla Cypria of 1260 (Coureas, 1997, pp. 291-292 and 296).

This agreement was formulated by the papal legate Eudes de Chateauroux and accepted by the Greek archbishop Germanos and the Greek bishops of Lefkara, Arsinoe and Karpasia. All of these localities were within the respective Latin suffragan dioceses of Limassol, Paphos and Famagusta. They essentially reiterated the provisions of the 1220 and 1222 agreements, but with added clauses. Annual visitations of Greek monasteries by Latin bishops were limited and so were expenses payable by the Greek clergy, while Greek bishops had the same authority over Greek monasteries and priests as their Latin equivalents had over Latin monasteries and priests. Greek ecclesiastical courts could continue functioning in localities traditionally having them, although appeals against their decisions would go to the Latin diocesans and ultimately to the Roman Curia (Schabel, 2010, vol. 1, f-35; Coureas, 1997, pp. 297-300). The family law applied in these courts has survived in a manuscript written between the years 1260-1306 by an anonymous Greek cleric for the Greek Episcopal court of Arsinoe. It consists of ten articles, five on procedural law and five on substantial law. The more modern editions of these laws acknowledge the influence of the Latin summae in circulation throughout Western Europe from the twelfth century onwards (Simon, 1973, pp. 7-8; Maruhn, 1981, pp. 218222; Aimilianides, 2004, pp. 55-56). The Greek clergy were also granted authority over the Melkites, Greek-rite Syrian Christians. Archbishop Germanos, while acknowledging papal jurisdiction, was to be completely free from the jurisdiction of the Latin archbishop of Nicosia as long as he lived. After his death, however, the Greeks of Cyprus would cease to have their own archbishop. His successor, the bishop of Solea, would be directly subordinate to the Latin archbishops of Nicosia. Archbishop Hugh of Fagiano, disgusted on account of not having Germanos placed under his jurisdiction, left Cyprus after the agreement never to return (Schabel, 2010, vol. 1, f-35, no. 20; Coureas, 1997, pp. 300-302). Nonetheless, despite continued Greek resentment, it lasted until the Ottoman conquest of 1570 .

Splits within the Greek Church over relations with the Latins and occasional conflicts continued after 1260. Greek priests in the Nicosia 
diocese opposed to the provisions of the Bulla Cypria are recorded as having uprooted the vines and driven their colleagues accepting it from their houses, who then sought refuge with the Latin archbishop of Nicosia. The regulations of a Latin provincial synod convened under Archbishop Ranulf condemned those Greek clergy refusing to accept Latin doctrines, especially regarding the validity of unleavened bread, as heretics and the Greek bishop Matthew of Lefkara narrowly escaped arrest on the orders of the Latin Dominican Bishop Berard of Limassol for persistently refusing to recognize its validity (Coureas \& Schabel, 1997, nos. 11, 75-77, 79 and 81; Coureas, 1997, pp. 302-311; Schabel, 2001, pp. 142-145; Schabel, 2010, pp. IV 227-234). Yet there are instances of Greek clergy recognizing the authority of their Latin counterparts. On Bishop Matthew's death the Greek clergy solicited and obtained Bishop Berard's approval for the election of his successor, in accordance with the terms of the Bulla Cypria. Sometime before 1301 the two disappointed candidates for the abbacy of St George of Mangana appealed to the pope against Leo, albeit unsuccessfully. Attempts by Latin clergy in Cyprus in 1306 and 1308 to have the Greek monks of the monasteries of St George of Mangana near Nicosia and of three Greek monasteries in Paphos replaced by Latin monks were unsuccessful, partly because most Latins in Cyprus and therefore most establishments of the Latin church were concentrated in the capital Nicosia and in Famagusta, the island's main port. Indeed, in the early fourteenth century Abbot Germanos of St George of Mangana successfully prevented various Latins and Greeks from despoiling his monastery's property by appealing to Pope John XXII (Coureas, 1997, pp. 312-316; Coureas, 2010, pp. 460-465).

What conflicts did occur with the Latin Church in the fourteenth century were caused by visiting papal legates. In 1314, Peter de Pleine Chassaigne, the titular patriarch of Jerusalem, had the Greek bishops of Solea and Lefkara gaoled for refusing to accept new regulations whereby the Greek practice of prostration before the Host after its benediction and before its consecration was proscribed as being idolatrous. The Greek bishops were instructed to convene a synod twice a year shortly after the convening of a Latin provincial synod, to celebrate orders at the same time as the Latin clergy and to receive the chrism prepared by the Latin bishops. The Greek bishops opposed these rulings as contrary to the Bulla Cypria and following the intervention of Pope John XXII they were released, although instructed to clarify to their congregations that the Host did not become the body and blood of Christ prior to its consecration (Coureas, 2010, pp. 426-428; Schabel, 2001, pp. 341-349). In 1360, the Carmelite friar and papal legate Peter Thomas provoked a riot in the Latin cathedral of the Holy Wisdom in Nicosia when he preached to the bishop of 
Solea and other Greek clergy summoned there on the errors of their ways. He also tried to force them to accept the Latin sacrament of confirmation according to the fifteenth century Greek chronicle of Leontios Makhairas. King Peter I sent a force of mounted sergeants to disperse the Greeks rioting. St Brigit of Sweden likewise viewed the Greeks of Cyprus and their church as insubordinate to Rome. When preaching in Famagusta in 1372, she warned the Greeks that their empire would face destruction if they did not acknowledge papal primacy, although conceding that those Greeks not aware of the need to submit to Rome and otherwise living as good Christians would attain salvation (Coureas, 2010, pp. 448-450; Smet, 1954, pp. 92-93; Dawkins, 1932, vol. 1, paras. 101-102; Kezel, 1990, p. 199).

Yet, the scarcity of Latin clergy, especially outside Nicosia and Famagusta, worked to the advantage of the Greek Church. Although the Constitutions of the Latin provincial synod held in 1340 under Archbishop Helias of Nabineaux record the formal acceptance of the fundamental articles of the Roman Catholic faith by the Greek clergy and those of other rites present, in practice they appear to have been a dead letter. In 1353, Archbishop Philip de Chamberlhac passed rulings stating that Greeks and Latin intermarrying had to wed and raise their children according to the Latin rite and that priests of each rite could only administer the sacraments to persons of the same rite, except in cases of Greeks wishing to go over to the Latin rite, who would then receive the Latin sacrament of confirmation from Latin priests. Pope Urban V's letter of 1368 to Archbishop Raymond de la Pradele alludes to complaints King Peter I of Cyprus had submitted to him about Latin nobles not receiving the sacraments in the Latin cathedrals of the island and of Latin noblewomen frequenting the churches of "Greeks and schismatics" (Coureas \& Schabel, 1997, no. 131; Schabel, 2001, pp. 248-271; Coureas, 2010, pp. 444-448).

Major rural Greek monasteries such as those of Makhairas, St George of Mangana, which had dependencies as far away as Cilician Armenia, St Margaret of Agros, and Neophytos the Recluse were able to survive throughout the periods of Lusignan and Venetian rule, although the smaller monastery of the Holy Cross of Lefkara lost its independence and was united to the Episcopal mensa of the local Greek bishop. Major Greek monasteries outside Cyprus, like St Catherine of Sinai, and SS Savvas and Theodosios in Palestine owned properties throughout Cyprus. In the towns, the churches of St Barnabas and Panagia Hodegetria functioned as the main Greek churches of Nicosia after the early fourteenth century. In Famagusta, the church of St George of the Greeks built in the midfourteenth century rivalled the Latin cathedral of St Nicholas in size and splendour (Coureas, 2010, pp. 459-473; Coureas, 1996, pp. 475-484; Richard, 1986, pp. 61-75; Schabel, 2012, pp. 160-161; Olympios, 2018, p. 314). 
Nicosia was home to the Greek monasteries of St John of Bibi, the Andreion, Neankomos, "de Lagro" and Stavros ho Phaneromenos recorded from the mid-fourteenth century onwards, as well as to the nunneries of Phaneromeni, All Saints, the Gynaikeion and Pallouriotissa, the records for which are mainly from the fifteenth and sixteenth centuries. The monasteries of St Yerasimos and St George of Dadi as well as the church of St Epiphanios are recorded as existing in Famagusta and the surrounding district in the fourteenth century (Schabel, 2012, pp. 166 and 168172; Coureas, 2010, pp. 473-474). Despite losing lands to the incoming Latin rulers and nobles after 1191 and witnessing a drastic reduction in the number and powers of its bishops from the 1220s onwards, the Greek Church retained a powerful presence throughout urban and rural Cyprus.

The patronage that the Lusignan kings and nobility extended towards the Greek Church helped it retain such a presence. They offered their support by endowing Greek monasteries and churches. King Henry II (1285-1324) or King Hugh IV of Cyprus (1324-1359) placed the Greek monastery of Our Lady at Neankomi just outside Nicosia under royal protection, exempting it from fiscal and servile obligations. The fifteenth century Cypriot chronicler Leontios Makhairas recounts how the Holy Cross of Tochni, scorned by Latin prelates but proven to be miraculous when it survived placement in fire and restored the power of speech to Alice d' Ibelin, King Hugh's wife, impelled her to found a Greek church at Hagios Dometios, also near Nicosia, for preserving a fragment of the True Cross. According to Ephraim the Athenian, King Peter I of Cyprus (1359-1369) and his wife Eleanor of Aragon had the damages caused by fire to the Greek monastery of Kykko in 1365 repaired in six months. King Peter I also arranged for the monastery of the priests (ton Hiereon) in the diocese of Paphos to receive financial assistance from Balian de Soissons, the baillif of the royal finance office, the so-called secrète, and had the church at the village of Menoiko rebuilt and granted the relics of SS Kyprianos and Juliana. The coats of arms of the Lusignan kings and of prominent Latin noble families, the Dampierres, the Chappes, the Morfs and possibly the Montolifs are found on churches in the Troodos mountains, at Kaliana, Pedhoulas and Kalopanayiotis, an indication of noble as well as royal patronage (Grivaud, 2007, pp. 259-262; Dawkins, 1932, vol. 1, paras. 67 and 69-77; Coureas, 2010, pp. 437-439).

Whether the patronage of the Lusignan kings derived from that exercised formerly by the Byzantine emperors or from their position as feudal lords regarding Greek monasteries located in the royal domain is uncertain due to the paucity of documentation. The lack of documentation also makes it impossible to determine the proportion of Greek monasteries forming part of Latin fiefs after 1191 as opposed to those retaining full 
ownership of their properties. According to the agreements of 1220 and 1222 Greek abbots had to be elected canonically and have the assent of the lay lords on whose lands their monasteries were situated. This was done with the aim of limiting the number of Greek serfs becoming monks in order to escape their feudal obligations towards the Latin lords. The same accords prohibited any interference by the Latin rulers or lords regarding the properties the Greek churches, abbeys and monasteries had possessed from Byzantine times. In the course of time, however, the rights of Latin lay lords to approve the election of Greek abbots disappeared, as appears from the report of the 1480s that a cleric of the Latin cathedral of the Holy Wisdom of Nicosia prepared for Benedetto Soranzo, the incumbent archbishop of Nicosia. This weakening of temporal rights enjoyed by Latin nobles over Greek monasteries is perhaps proof of the libertas ecclesie promoted by the papacy. Nevertheless, the sparse documentation, especially when compared with the more abundant documentation from Venetian Crete and Hospitaller Rhodes, does not permit of a firm conclusion (Coureas \& Schabel, 1997, nos. 82-84; Voisin, 2013a, pp. 395-396 and 399-403).

The Lusignans and the Latin nobles also promoted the cult of Cypriot saints. King Hugh IV before 18 May 1353 had granted an income of 400 white bezants to the Latin cathedral of the Holy Wisdom in Nicosia, part of which was allocated for the celebration of SS Barnabas, founder of the Church of Cyprus, and Epiphanios, the famous bishop of Salamis (Coureas \& Schabel, 1997, no. 130). The hermitage of St Sozomenos above the homonymous village to the south of Nicosia was embellished with high quality paintings in the mid-fourteenth century and again in the fifteenth and sixteenth centuries, when this village and the nearby Potamia belonged to the royal domain. The worship of St Mamas, first attested in Cyprus during the twelfth century, expanded during the Lusignan period, when according to Leontios Makhairas - it was promoted in Nicosia, Famagusta and Limassol, with a Greek nunnery dedicated to him recorded in 1375 in Nicosia. A second monastery dedicated to St Mamas appeared in Morphou, that had become part of the royal domain under King Hugh IV in 1324, during the late fourteenth or early fifteenth century. As there were no wealthy Greek burgesses there to finance this monastery's construction, it was probably built on account of Lusignan patronage (Dawkins, 1932, vol. 1, paras. 429 and 570; Grivaud, 2007, pp. 263-268).

\section{The later Lusignan period (1374-1473)}

Following the war between Cyprus and Genoa, which resulted in the Genoese occupation of Famagusta until 1464, the Latin crown, nobility and 
church of the island were weakened. Absenteeism among the island's Latin clergy, already a problem in the previous period, increased as time went on, while the papal schism of 1378-1417 with rival popes in Rome and Avignon further weakened the Latin Church on Cyprus. The archbishop of Nicosia and his suffragans of Paphos and Limassol supported Pope Clement VII in Avignon, while the bishop of Genoese-occupied Famagusta backed Pope Urban VI in Rome. This presented an opportunity to the Greek Church of Cyprus (Hill, 1948, pp. 1084-1085; Collenberg, 1982, pp. 621-631; Kyriacou, 2018, pp. 132-133). By the early fifteenth century, it felt confident enough to seek secret communion with the ecumenical patriarchate of Constantinople, while outwardly remaining subordinate to Rome. In 1405, the learned Constantinopolitan monk Joseph Bryennios, who between the years ca. 1382-1402 had served as the judge and instructor of the Greeks of Venetian Crete, prior to his expulsion from the island after publicly rejecting the Latin filioque doctrine, was assigned the task of examining this application. In 1412, he resolutely rejected it before a council of Orthodox clergy convened in Constantinople. He pointed out the hypocrisy of such an arrangement and the deleterious effect it would have on other Orthodox churches in areas under Latin rule. Yet, even in this instance, the split within the Greek Church between those advocating resistance and those desiring an accommodation with the Latins shows through, for the Greek bishop of Lefkara in the diocese of Limassol was absent on account of being a "Latinizer." Furthermore, Bryennios himself castigated the Greek clergy of Cyprus for attending religious functions organized by the Latin Church. Among his other arguments, he makes the interesting observation that whereas the Latins and various other Christian confessions on Cyprus faithfully adhered to their traditional rites, the Greek church of Cyprus, in administering the sacraments, had adopted many rites not only of the Latins, but of the other Christian denominations present on the island. He castigated the Greek clergy for their attendance of religious processions, festivals and funerals organised by the Latin Church (Hackett, 1923, pp. 186-196; Hill, 1948, pp. 1085-1088; Coureas, 1998, pp. 83-84; Kyriacou, 2018, pp. 134-151).

Despite Bryennios' final observation, a letter of 1441 written by the Greek bishops of Cyprus to Pope Eugenius IV in the wake of the Council of Florence of 1432, in which the union of the Catholic and Orthodox churches was formally proclaimed, complained that even if the Latins on Cyprus had formerly quite properly abstained from maintaining social intercourse with the Greeks while the Catholic and Orthodox churches were separate, they were nonetheless continuing to do this following the union achieved at the Council of Florence, disdaining to invite the Greek clergy in accordance with their station to weddings, funerals and other 
public functions even though they no longer had cause to snub them. Indeed the Latins had expressly forbidden such fraternization, maintaining that such behaviour would occasion scandal. Andreas Chrysoberges, a Uniate Greek who was the archbishop of Hospitaller Rhodes at this time, was urged by the Greek bishops of Cyprus "and other loyal Greeks of the said kingdom" to compel the Latin clergy on pain of ecclesiastical censure to invite them to such functions in a spirit of welcome. In passing on the letter to Chrysoberges, the pope instructed him to examine the truth of these allegations, and, should they prove correct, to ensure that the Latins entered into social relations with these loyal Greeks desiring this (Hofmann, 1946, pp. 40-41 and note 1). Even if Joseph Bryennios was wrong about the Greeks taking part in various processions of the Latin Church, some of the Greek clergy and laity on Cyprus apparently wished to do so. On the other hand, the letter Pope Nicholas V sent to Andrew Chrysoberges, the Greek Uniate archbishop of Rhodes, in August 1447, complained that Greeks on Cyprus and Rhodes were defiant towards the rulings of the Council of Florence, maintaining instead that the Latins had accepted the Greek creed (Hill, 1948, pp. 1091-1092; Kyriacou, 2018, p. 155).

Pope Eugenius IV's instructions to Andreas Chrysoberges were, at least to some extent, rendered superfluous by the increasing absenteeism of Latin prelates and other clergy from Cyprus. Indeed, the Greek bishops of Solea took advantage of the absenteeism of the Latin archbishops by residing in Nicosia on a permanent basis. According to the provisions of the Bulla Cypria of 1260, Archbishop Germanos and the Greek bishops of Solea who succeeded him were permitted to reside at the Greek church of St Barnabas whilst in Nicosia, but they normally had to be resident at Solea (Coureas \& Schabel, 1997, no. 78). By 1458, however, Bishop Nicholas of Solea appears to have been resident in Nicosia. He supported James, the illegitimate son of King John II of Cyprus by his Greek mistress, Maria of Patras, in his attempt to seize the throne from Queen Charlotte in December 1458. He was likewise in Nicosia when King James II died and his wife Catherine Cornaro was proclaimed queen along with her infant son James III in August 1473 (Hill, 1948, pp. 550-551, 617618 and 1093; Coureas, 2005, paras. 31 and 102). From the above termini ante and post quem one can deduce that Bishop Nicholas of Solea held this office for at least 15 years and appears to have resided in Nicosia. He was also the Greek bishop of Solea to whom Pope Sixtus IV alluded in his bull of mid-1472, in which he observed that the Latin church had long lacked a pastor in the city and diocese of Nicosia capable of defending its rights and liberties, and that for some time past, a Greek bishop from Solea had usurped all matters pertaining to the jurisdiction and to the Episcopal 
office of the Latin archbishop of Nicosia. This bishop was, moreover, presuming to exercise the archbishop's powers instead of confining himself to Solea, the only locality in which he could lawfully maintain an ecclesiastical tribunal (Coureas \& Schabel, 1997, no. 94).

The bull promulgated by Pope Sixtus IV in 1472, on the eve of the Venetian annexation of Cyprus, attempted to redress this situation in favour of the Latin Church. Passed with specific regard to the relations between the Latin and non-Latin clergy on Cyprus itself, the letter painted a bleak situation as regarded the Latin clergy on Cyprus. The Latin archbishop was an absentee while the Greek and other non-Latin bishops, such as Armenians and Jacobites, were exercising rights pertaining to the Latin diocesans throughout the Latin dioceses of Cyprus. Without seeking the permission of the Latin diocesans, they were conferring holy orders, often on morally unsuitable candidates, practising simony, blessing marriages within the prohibited degrees, and usurping the jurisdiction of the Latin archbishop and his suffragans in matrimonial and other spiritual issues. The provisions of the Council of Florence were being disregarded, and doctrinal errors were being disseminated, to the overall detriment of the Latin Church and its episcopate. To remedy this, the pope ordered the restoration of the rights of the Latin bishops, stating that non-Latin bishops were to exercise ecclesiastical jurisdiction only over their respective congregations, and were to cease exercising jurisdiction over matrimonial issues, or to grant marriage dispensations, divorces or separations. The Greek bishops were to exercise jurisdiction concerning the above matters only within the localities in which they were supposed to be resident according to the stipulations of the Bulla Cypria, on pain of excommunication. The contents of the above letter, if correct, indicate that the Greek and other non-Latin prelates were exercising ecclesiastical jurisdiction over Latins, something all the more credible in view of the absenteeism of the Latin archbishop as well as that of many other Latin bishops and prelates, a phenomenon which had assumed serious proportions from the fourteenth century onwards. Furthermore, the composition in Greek of a Florilegium between the years ca. $1439-1550$ by a Cypriot Franciscan friar named Francis affirming the existence of Purgatory and of the Beatific Vision, elements of the Roman Catholic faith denied by the Greeks, indicates that the Latin Church on Cyprus was on the defensive doctrinally as well (Coureas \& Schabel, 1997, no. 94; Hill, 1948, pp. 1094-1095; Kyriacou, 2018, pp. 157-159, 162-163 and 247-250). 


\section{Greek churches and monasteries in the later}

\section{Lusignan period}

There is documentary evidence for a number of churches in this period. A document written in December 1460, describes how a protopapas named Kyriakos bequeathed some houses to his son Anthony, also a priest. The document alludes to two churches, Our Lady of Engomi and St Nicholas, and both were described as being situated in the area near the village of Ayios Dometios to the west of Nicosia. Clearly there was a settlement there, which later developed into the present-day suburb of Engomi. Indeed Our Lady of Engomi, described as a church in the above document, was in reality a monastery first mentioned in an earlier document in which the king of Cyprus granted the royal monastery of Neankomos, dedicated to Our Lady and located outside Nicosia, to a loyal subject of his by way of rewarding him. The earlier document is undated and both the king and the beneficiary unnamed, while Spyridon Lambros who published the document initially dated it to the thirteenth century and subsequently to the fourteenth. One notes that in 1405 a certain Thomas of Sour also called Kalamouneotis, was ordained priest in the church of Neankomou in March 1405, while the monastery itself continued to be in existence until the early part of the nineteenth century. Besides the churches and monasteries mentioned above, there were other Greek churches and monasteries in Nicosia for which we have only isolated references. Among them are the churches of St Nicholas of Soulouan and of St Nicholas "tou Querachi," as well as that of St Luke the Evangelist, all mentioned in the Livre des Remembrances for the years 1468-1469 (Angelomatos-Tsougaraki, 1995, pp. 171-175; Richard, 1983, nos. 167, 206-207 and 214).

Turning to the Greek monasteries, one observes that St Mammas was a notable Greek monastery of Nicosia which as mentioned above figures in the chronicle of Leontios Makhairas. Makhairas recounts how Thibaud of Belfarage, a knight of Syrian origin whom he criticises for having crossed over from the Greek rite to the Latin one, murdered the Latin priest Sir Philip outside this monastery. Sir Philip had gone there to visit his mother who had become a nun at the monastery. Both Thibaud of Belfarage's crossing from the Greek to the Latin rite and the fact that the Latin priest Sir Philip had a mother who had become a Greek nun illustrate how within fourteenth century Cyprus people could change confession, as well as how people of the same family could belong to different rites. In a document of 1468 St Mammas is mentioned as paying an annual tax assessment of 300 bezants (Dawkins, 1932, vol. 1, paras. 566-569; Mas Latrie, 1855, p. 281).

The monastery of St John the Evangelist of Bibi, founded by the Bibi family originating from Syria, was a burial place for Syrian Melkites in the 
later fourteenth century. Furthermore, it was also mentioned by Joseph Bryennios during his visit to Cyprus in 1406 as a monastery whose monks had been ordained by Orthodox clergy from outside Cyprus not subject to the Bulla Cypria and its provisions, who considered themselves to be the only genuine Orthodox clergy on Cyprus (Kyriacou, 2018, p. 144; Coureas, 2019, pp. 89-90). It is also mentioned in an act of March 1468. A certain Philip Vacla, who had obtained the use of a flour mill at Kythraea from Philip David, who had leased the mill for five years, accepted the obligation to pay the taxes of this monastery from the incomes of these mills. In November 1468 the monastery's executor Andreas Salah, who was clearly of Syrian origin, gave notice that he had received the annual revenues due to the monastery from the casale of Episkopi, amounting to 1433 bezants. In January 1469 the monastery, which had recovered the rights it enjoyed over the priestery of St Niketas near the casale of Lakatamia, leased those rights to a certain Philip Jura, who undertook to pay just over one third of the rent of 122 bezants to the Greek monastery of St George of Mangana and the balance to the monastery of St John of Bibi. Philip Jura also undertook to have restored the church of St Niketas and the two buildings attached, on pain of having to pay 500 bezants along with interest and damages (Richard, 1983, nos. 187, 195 and 217-218).

\section{The Greek Church in Venetian Cyprus (1473-1571)}

In Cyprus as in their other overseas colonies Venice sought to control the local clergy, Greek and Latin, and this entailed control over Episcopal appointments. This in practice meant the exclusion of the Greek clergy from the election process according to the terms of the Bulla Cypria, although in August 1477, while Catherine Cornaro was still queen of Cyprus, the Venetian Senate decreed that the custom of obtaining the crown's consent for the election of Greek bishops and abbots should be respected and that any sums of money given in connection with this were to go to the royal treasury. The allusion to this custom suggests that the crown was intervening in Episcopal elections from the later Lusignan period onwards, and Stephen de Lusignan likewise believed, albeit mistakenly, that this right of the crown was in the provisions of the Bulla Cypria. Although the evidence is inconclusive it is possible that in this regard the Venetians were simply adapting practices inherited from the later Lusignan monarchs (Mas Latrie, 1855, p. 414; Arbel, 2009, pp. 374-375).

The two authors of the report known as the Memoria, prepared for the Venetian archbishop of Nicosia Benedetto Soranzo following his appointment in 1485, state curiously regarding the Greek clergy of Cyprus that 
Greek deacons, priests and the laity in general on Cyprus were subject to the jurisdiction of the Lusignan crown, whereas in other instances Greek clergy and laity were subject to the jurisdiction of the Latin archbishop of Nicosia. This assertion is wholly unfounded. Since the promulgation of the Bulla Cypria in 1260 all the Greek clergy on Cyprus recognised papal primacy and came directly under the jurisdiction of the Latin archbishop of Nicosia and his suffragan bishops of Famagusta, Limassol and Paphos. Their assertion, however, was probably influenced by the situation regarding the Greek clergy on Crete, a Venetian possession since 1211. The lower ranking Greek clergy consisting of 130 priests came under the jurisdiction of the Latin archbishop of Crete while the four arch-priests or protopapades at the top of this hierarchy, not chosen from 1360 onwards from among the 130 priests under the Latin archbishop, came under the authority of the secular Venetian authorities in Crete. If this observation in the Memoria indicates a desire on the part of Venice to introduce a similar separation of jurisdictions among the Greek clergy of Cyprus this was never implemented (Voisin, 2013b, pp. 113-114; McKee, 2000, pp. 104-106).

From the start of the Venetian period the problem of simony within both Latin and Greek churches was mentioned, a phenomenon that possibly existed earlier without being reported. The abovementioned Memoria stated that Greek and Latin benefices were sold at public auctions that the clergy of both confessions sought to free themselves of episcopal control both as regarded their election and their confirmation in office. Simony was practiced in the election of Greek secular clergy, bishops and even simple clerks, and it extended to the Greek monastic clergy as well (Voisin, 2013b, pp. 102103 and 108). In 1490 the Venetian lieutenant of Cyprus transmitted a complaint to the Venetian government on behalf of the Cypriots. It stated that vacancies to Greek and Latin churches under the ius patronatus of the kingdom were sold to the highest bidder, and that this even applied to bishoprics, abbotships and Greek priories, regardless of whether the candidates were ecclesiastics or laymen, suitable or not, literate or unlettered. These churches had come to ruin, the persons appointed to them were usurping and plundering their goods and the divine offices were being reduced. The Venetian government was asked to put a stop to this state of affairs, but their response was in general non-committal, although it was stated that the Venetian rectors on Cyprus could undertake the repair of neglected churches and monasteries with the incomes of the attached benefices (Mas Latrie, 1882, pp. 529531; Hill, 1948, p. 778).

Indeed, Venice practiced simony at the start of the sixteenth century to raise money for her own expenses in the war against the League of Cambrai. Candidates to Greek benefices were asked to lend money to finance 
the arming of galleys, two examples being the priest Demetrios, oikonomos of the church of St Eleousa in the diocese of Nicosia, offered the abbacy of the monastery of St Mamas if he lent 600 ducats for equipping a galley, and the priest Andreas, who offered 500 ducats to obtain the Greek bishopric of Karpasia in the diocese of Famagusta. In 1510 the Greek abbot of St Mammas near Nicosia, erroneously referred to as Santa Maura by Sir George Hill, offered to pay a good price for the bishopric of Nicosia, the price being 1,500 ducats or more "as is customary" and he was recommended by the Venetian captain of Cyprus. In 1521 the Greek bishop of Nicosia appeared before the college of Venetian rectors with the complaints that attempts were being made to deprive him of his authority, even though he had paid 2,000 ducats for this office. Financial necessity also impelled the Venetian Senate in 1512 to pass a decree stating that Orthodox communities of up to 30 families should be served by no more than one priest or deacon, in order to prevent too many free peasants, the so-called francomati from escaping their obligations to work on building fortifications by joining the priesthood (Hill, 1948, pp. 778-779; Skoufari, 2011, p. 104 and notes 47 and 49; Aristeidou, 1993, p. 194 note 4).

The Venetians nonetheless took some steps to combat simony. From 1490 onwards, the Venetian Senate decided that the lieutenant and his two councillors in Cyprus should each propose a suitable candidate for vacant churches, either Cypriots or persons from other Venetian territories who had resided in Cyprus for at least five consecutive years. The College would then elect one of the three candidates and limit the time in which a church remained vacant. Their choice would be entrusted to a majority in the reggimento, the Venetian administration on Cyprus, which would then simply inform the authorities in Venice so as to obtain confirmation of the election. In the same year, an embassy consisting of representatives of the ruling groups on Cyprus tried to put an end to the simony behind the formal election processes of Greek clergy, especially bishops, abbots and priors. It requested that the elections of literate and suitable candidates should follow consultation with the gentry and other local citizenry, although the election procedure was not precisely specified. In 1506, however, the Venetian Senate received a Cypriot delegation on the same subject which expounded the current election process then followed. On the death of a Greek bishop, the Venetian rectors would propose three candidates, and the Venetian metropolitan authorities would make the choice. In response to their overtures, the Senate in 1507 took the radical step of entrusting the election of Greek bishops to the urban assembly of Nicosia, with the Senate confirming their choice. The urban assembly of Nicosia was also granted the power of proposing Greek bishops for the districts of Famagusta, Limassol and Paphos, although in 1552 the urban assembly 
of Famagusta petitioned the Venetian authorities (without success) for the right to elect their own bishops (Arbel, 2009, pp. 375-378; Birdachas, 2011, pp. 133-134; Skoufari, 2011, pp. 102-104).

Mindful of the fact that Cyprus, like other Venetian overseas possessions, had a Greek majority population, the Venetians sought to avoid antagonizing the Greek clergy. Hence despite a ruling that every newly elected Greek bishop had to journey to Venice to receive confirmation of his election, in 1507 the Cypriot Greek bishops were dispensed from having to undertake this long and expensive journey from Venice's furthermost possession. Instead, they had to present themselves before the Venetian authorities in Nicosia that would request the required written confirmation from the Venetian Senate (Skoufari, 2011, p. 100). Nevertheless, the procedure the Venetians introduced for the election of Greek bishops ultimately alienated them from the ordinary Greek clergy without necessarily guaranteeing the loyalty of the bishops elected from the candidates proposed by the urban assembly of Nicosia to Venice. The examples we have of this procedure all date from 1543 onwards, although it may have been followed earlier. Indeed, it resembled the procedure applied in Venice itself until 1510 for the Latin prelates in Venetian territories, although the latter, unlike their Greek counterparts, also needed papal confirmation, whereas the Greek bishops of Cyprus were simply consecrated by the Latin diocesans of their districts. The system introduced for electing Greek bishops increased the overall hostility of Greek clergy towards Venice. One observes that the popular teacher and medical practitioner, James Diassorinos, arrested by the Venetians in 1562 for conspiring to overthrow Venice and hand Cyprus over to the Ottomans, was arrested in the house of the Greek bishop of Paphos, while the three ringleaders hanged in 1566 for fomenting bread riots in Nicosia against Venice included a Greek priest (Arbel, 2009, pp. 378-380; Coureas, 2021, p. 128).

The conspicuous presence of the Greek clergy in Cyprus and more especially in Nicosia under Venice is attested by the Dominican monk of Ulm, Felix Faber. He visited Cyprus in 1483 and described Nicosia as having many churches, both Greek and Latin. He reported the Greek churches possessed towers and wooden instruments for summoning the people to the divine offices. Early in 1508, the Tyrolese pilgrim Baumgarten also visited Cyprus. He observed that Nicosia, Famagusta and Paphos had "double" episcopal sees, so that there was a Greek and a Latin bishop in every city. In 1519, Jacques le Saige, a merchant from Douai, visited Cyprus and remarked on how Latin and Greek masses were celebrated in separate areas of a church at Salines near Larnaca (Cobham, p. 42, 54 and 60). The Greek clergy in Cyprus seem to have been in a better position with regard to their Latin counterparts than in other areas under Latin 
rule with Greek populations. In 1521, Pope Leo X issued a bull reaffirming the concessions granted to the Greek clergy at the Council of Florence in 1432, which the Latins had allegedly been trying to nullify, such as the continued practice of the Greek rite or the appointment of Greek prelates in areas of mixed Latin and Greek populations, such as Southern Italy and Sicily. The above bull was renewed and confirmed in 1526 by Pope Clement VII, something that suggests that the Latins in Italy and Sicily were continuing their attempts to nullify these concessions (Tsirpanlis, 1972, pp. 845-877; Skoufari, 2011, p. 99).

An examination of the terms of these bulls makes it clear that they allude to conditions frequently inapplicable to Cyprus. Neither of them had been promulgated with regard to conditions specific to Cyprus and they passed over the Venetian innovations of 1507 regarding elections to vacant Greek bishoprics. In the early sixteenth century, Venice ruled several Greek islands, including Crete and the Ionian islands. Unlike Cyprus, these lands had not been former Latin kingdoms and features governing the relations between Latin and Greek clergy in Cyprus, like the Bulla Cypria of 1260, did not apply there. Greffin Affagart of Maine in France visited Cyprus in 1534 and likewise observed that there were Latin and Greek churches in each town, and separate Latin and Greek bishops, although he does not state whether the Greek bishops were resident in the towns or in the localities allotted to them according to the Bulla Cypria (Cobham, 1908, p. 66). The revenues of the Greek bishops of Cyprus show a slight increase under the Venetians, at least for the period from the start of the sixteenth century to 1529. At the beginning of this period, the Greek bishops in the districts of Nicosia, Paphos, Limassol and Famagusta had annual incomes of 600, 400, 200 and 200 Venetian ducats respectively, totalling 1400 ducats. By 1529, the same Greek bishoprics had a total income of 1600 ducats, a slight increase and not a diminution as Skoufari mistakenly asserts. No figures are unfortunately extant for the later years of Venetian rule (Hill, 1948, pp. 1098-1099; Skoufari, 2011, p. 101).

Despite Venetian procedures aimed at securing candidates to Greek Episcopal vacancies via the urban assembly of Nicosia, as mentioned above, the Greek bishops were regarded as recalcitrant and troublesome towards the end of the period of Venetian rule, and were seen as inciting the Greeks to disobedience. In 1562, Bernard Sagredo, who was the general provveditor appointed by Venice to Cyprus, alluded to the fact that the Greeks bishops of Solea were resident in Nicosia, recommending that the four Greek bishops and especially the bishop of Solea should be deprived of their offices. He reasoned that without them, all the people would obey the Latin archbishop of Nicosia and the Latin bishops, since the Greek bishops "are ignorant and malicious towards those observing 
the rites of the Roman Curia” (Mas Latrie, 1855, p. 542). Giovanni Antonio Facchinetti, the apostolic nuncio to Venice between the years 15661573, favoured proselytizing so as to bring the Greeks over to the Latin rite, believing that this would make them more loyal to both Venice and the papacy. He suggested disestablishing wealthy Cypriot bishoprics so as to create benefices accessible only to Latin rite clergy. He argued that this would encourage many Greek clergy to convert to the Latin rite so as to obtain these benefices, which in turn would cause others to follow them, while he, the Latin bishop of Paphos Francesco Contarini, and Astorre Baglione, who commanded the Venetian militia in Cyprus, all favoured the creation of a Jesuit College there (Skoufari, 2012, pp. 228-229). By this time, Protestatism had made an appearance on Cyprus. Members of the aristocratic Greek Syglitico family were accused of spreading Lutheranism by the Roman Catholic Inquisition and in 1564 Franzino Synglitico, nephew of the Greek bishop of Karpasia, was sentenced to death for this offence. Protestant doctrines, however, did not spread to Greek Cypriots outside the aristocracy (Kyriacou, 2018, pp. 190-192).

By this time, the decrees of the Council of Trent gave rise to a new dispute. Philip Mocenigo, the last Latin archbishop of Nicosia, was elected by the Venetian administration in March 1560. On 19 December 1560, Pope Pius IV granted the right to choose the archbishops of Nicosia to Venice. Mocenigo, whose background was secular and administrative prior to his becoming archbishop, was present in Cyprus from December 1560 to confirm this agreement between Pope Pius IV and Venice. He was accompanied by two Portuguese Jesuits who planned to found a college on Cyprus, although they departed a few months later without accomplishing this. From 1565 onwards, Mocenigo attempted to apply the decisions of the Council of Trent to both the Latin and Greek churches of Cyprus: he is probably responsible for the unpublished report on the "errors" of the various rites on Cyprus, composed after 1563. The Greek bishops resisted his plans and Neophytos Logaras, the Greek bishop of Solea, maintained that there was a dividing line between the two rites, with him being responsible for the Greeks' spiritual welfare just as the Latin archbishop was responsible for that of the Latins. The Venetian Council of Ten wrote in April 1565 to the Venetian authorities of Cyprus on the reluctance of the island's Greek bishops to publicize the decrees of the council of Trent, something which both the authorities and Mocenigo himself had made known to them. They instructed them to tell Mocenigo and to have him tell the other Latin bishops to postpone any actions with regard to the Greek bishops, to consider the Council's instructions as confidential and await further instructions from Venice. In his report to the Venetian Senate of 1565 Bernardo Sagredo stated that the Greek bishops had threatened to foment 
a revolt against Venice if the Latin prelates were allowed to publicize the decrees of the Council of Trent. This would explain Venetian reluctance to allow Mocenigo free rein (Hill, 1948, pp. 1101-1102; Ntokos, 2002, p. 212; Birdachas, 2011, pp. 136-137; Skoufari, 2012, pp. 206-207, 209-211, 217218 and note 38; Coureas, 2012, p. 136 and notes 118-119).

Mocenigo, however, took further measures. In October 1565, he ordered all possessors of ecclesiastical benefices to come to his archbishopric to have them confirmed. This angered not only the Greek clergy but the Venetian authorities, given that they had the right to appoint candidates to such benefices, including the four Greek bishoprics and the Greek abbacies in Cyprus, and he was told to desist. In January 1567, he convened a provincial synod attended by Latin, Greek and other clergy. Among other objectives, he sought the appointment of six inquisitors with powers to ensure that the clergy were adhering to correct doctrines and lifestyles. Logaras opposed this measure with prevarications and his eventual arrival at the Latin archbishopric on 3 February 1568 to discuss it with Mocenigo was allegedly accompanied by an irate Greek crowd, who hammered on the building's door demanding their bishop's return. Mocenigo accused Logaras of allowing divorces and granting benefices to unsuitable candidates according to how much they paid. Logaras stated that while not denying the archbishop's authority he was unwilling to see his own diminished, either by Latin prelates or by the urban assembly of Nicosia. Mocenigo finally had Logaras summoned to appear in Rome before the Roman Curia, the authority of which Logaras denied as applicable to him. Indeed, following Venetian intervention he was taken not to Rome but to Venice instead (Ntokos, 2002, pp. 213-214; Skoufari, 2011, pp. 110-111; Skoufari, 2012, pp. 222-224).

There he appeared before the Council of Ten and was exonerated sometime before February 1568, when the Council of Ten wrote to the Venetian provveditore on Cyprus and the government. The document instructed them to prohibit the archbishop and the other Latin bishops on Cyprus from introducing any new innovation regarding the traditional rites of the Greek Church or to have any Greek bishop summoned to Rome. In its preamble, the letter stated that the Latin and Greek clergy of Cyprus should co-exist peacefully without intervening in each other's rites or jurisdictions, thereby vindicating Logaras. A letter of the same date sent to the Venetian ambassador in Rome instructed him to make it known to the Holy See or any other important person broaching the subject that great tumult would arise in the Levant if the ancient rites of the Greeks, long tolerated by the Roman Church itself, were interfered with. It was emphasized in view of the Turkish threat that now if ever was the time to show respect to these Greek traditions. Countering papal protests that 
heresy was being permitted under the cover of alleged respect for different rites, the Venetian ambassador to Rome replied that Logaras had been rebuked in Venice and that other members of the Roman Church besides the Greeks had different rites that had been deemed admissible in conciliar synods (Ntokos, 2002, pp. 214-215; Skoufari, 2012, pp. 224-225; Birdachas, 2011, pp. 281-285).

The support Venice granted the Greek clergy of Cyprus was not absolute, but conditional on securing the goodwill of the Greek populace. Hence in 1565 the Venetian government condemned the two usurers Calceran Zebeth and Marchio Fanuri who had been "sucking the blood of these poor inhabitants (of Cyprus) reducing many of them to poverty and to extermination." This condemnation was effected contrary to the wishes of the Greek prelates. In general, however, the Venetian authorities throughout sought to avoid provoking the Greek Church and by extension the Greek majority population of Cyprus, even to the extent of offending the Latin Church and Mocenigo in particular over implementing the decrees of the Council of Trent (Skoufari, 2012, p. 221). An incident that took place in a rural context likewise illustrating Venetian sensitivity to the religious feelings of the majority Greek population of Cyprus is the decision of the Venetian Senate in March 1560 to restore the treasure of 1721 gold ducats found by Cypriot peasants in the village of St Symeon in the Karpass peninsula in its entirety in June 1559. This was decided upon despite the standard procedure whereby one third of it would normally have been given to the state, one third to the captain of Famagusta and one third to the informant. The sum found was to be used to rebuild the village church, in line with the local saint's instructions to the villager responsible for the treasure's discovery (Arbel, 2002, pp. 1-19).

\section{Greek regular clergy, churches and monasteries in Venetian Cyprus}

Under Venice, the Latin prelates exercised only nominal supervision of the Greek regular clergy. Greek abbots were traditionally elected for life by the oldest and most respected monks of their monastery. They then presented themselves to the suffragan of the Latin cathedral of Nicosia for approbation, finally being confirmed in office by the Venetian authorities on Cyprus. In 1521, however, two procurators of the urban assembly of Nicosia, Eugene Singlitico and Zuan de Nores, asserted that this tradition had long fallen into abeyance, with the abbots appointed according to whatever amount of money they paid to the treasury. In response 
to repeated complaints over spiritual and moral failings of the abbots, the Venetian Senate decreed that their tenure of office should last only two years. Fantino Dolfin, an adviser to the Venetian authorities in Cyprus between the years 1542-1544, remarked that on account of lacking supervision by any superior, numerous Greek monks lived a lifestyle lacking religiosity and consuming church revenues without offering any benefit in return. In response to this, the Latin archbishop of Nicosia, Livio Podocataro, proposed entrusting visitations to a group of three monks elected by the monastic communities themselves, these monks being empowered to elect abbots, deprive incumbent abbots of office and assign monastic revenues. The Venetian authorities of Nicosia advised against this in a letter to the government in Venice, stating that this would create a tyrannical triumvirate that would destroy the religion of these monks. The Venetian lieutenant of Cyprus and his two counsellors also advised against a previous grant of the Venetian Senate whereby the urban assembly of Nicosia could elect eight Cypriot nobles, subject to approval by the local authorities, with powers to supervise and safeguard the good administration of Greek monasteries, and the sources yield no evidence for such an institution. In 1559, the urban assembly of Nicosia petitioned the Venetian authorities to extend the system for electing Greek bishops to be abbots of Greek monastic houses. The abbots ardently contested this proposal through their own emissary to Venice, Manasses Monachos. They apparently succeeded in thwarting the proposal, which increased the hostility of the Greek clergy towards Venice. They regarded any attempt at reform of Greek monastic life as unwarranted interference in their affairs (Skoufari, 2011, pp. 104-105; Arbel, 2009, p. 379).

The number of Greek monasteries in Venetian Cyprus is hard to establish, with various sources giving figures ranging from 35 to 61. The Venetian lieutenant of Cyprus, Sylvester Minio, stated in his report dated 1529 that there were 18 Greek monasteries and abbeys throughout Cyprus with a combined annual income of 6600 ducats, which, if true, meant an income of over quadruple that of the four Greek bishops in the same year. The monastery of St George of Mangana near Nicosia, mentioned above, continued to be the foremost Greek monastery in Cyprus under the Venetians. Following the fall of Constantinople to the Ottoman Turks in 1453, refugee monks from the city had come to Cyprus and were housed at the monastery by Helena Paleologina, the Greek wife of King John II of Cyprus, and the monastery was enriched by the villages and revenues given for their support. The queen's generosity appears to have been so great that Makhairas, writing in the fifteenth century, and the sixteenth century writers Florio Bustron and Stephen of Lusignan mistakenly attributed the monastery's foundation to her. According to a Venetian report 
written between 1510 and 1521 concerning the population of Cyprus, the number of villages and the revenues, including those of the island's Latin and Greek clergy, the Greek bishopric of Nicosia, and the monastery of St George of Mangana, both enjoyed annual incomes of 600 ducats. The monastery was demolished along with many other Latin and Greek churches and monasteries under the Venetians in 1567, in the course of the construction of the new walls of Nicosia (Skoufari, 2011, p. 104 and note 50; Richard, 1992, pp. XVIII 401-402 and notes 7-9; Mas Latrie, 1855, pp. 503-504; Lusignan, 1580, fol. 32v).

The monastery of St Mamas is also recorded during the Venetian period. On 30 May 1510, a priest Demetrios Doria became abbot of the monastery, on lending 500 ducats to the Venetian governor and another 100 to the Venetian authorities on Cyprus. He did not live, however, to enjoy his new office, for he died on the return journey from Venice to Cyprus. Nevertheless, the abbacy of the monastery was granted to his son, Paul Doria, then oikonomos of the church of the Virgin Mary Chrysodegetria, which was the Greek cathedral church of Nicosia. The abovementioned report of Sylvester Minio provides further information on the Greek churches and monasteries in Nicosia. In it, he refers to two Greek monasteries, of St John the Evangelist of Bibi and of the Virgin Mary of Andrion, stating that they had handsome incomes and significant relics. In the Venetian report of 1510-1521, the monastery of St John the Evangelist of Bibi is listed as having an annual income of 400 gold ducats, as much as the Greek bishopric of Paphos in the same period, making it second only to the Greek monastery of St George of Mangana in terms of revenue. The report of the Venetian lieutenant Francesco Bragadin of 8 November 1531 states the total revenues of the Greek monasteries and abbeys in the districts of Nicosia, Famagusta, Limassol and Paphos to be 1.500 Venetian ducats (Hill, 1948, pp. 778-779; Aristeidou, 1993, pp. 194-196; Mas Latrie, 1855, pp. 503-504; Birdachas, 2019, p. 112).

The monastery of the Virgin Mary of Andrion is mentioned in the same report as enjoying an annual income of 200 gold ducats, and is alluded to by Stephen of Lusignan writing in 1580, after the Turkish conquest, as one of the five Greek monasteries in Nicosia, the others being those of St George of Mangana, of Sergio and Flatro, of St John the Evangelist and of the Virgin Mary of Makedonitissa. According to a decision taken by the Venetian Council of Ten in 1558, the monastery of Andrion was to receive wheat and barley worth 25 ducats annually for the next ten years, so as to assist it in the completion of a church begun in Nicosia and dedicated to the Virgin Mary. Stephen of Lusignan also mentions several Greek nunneries, those of Phaneromeni, Hagioi Pantes, Gynaikeion, Pallouriotissa “and many others,” as he states. In 1544, the Greek nunnery in Pallouriotissa was one of the 
two nunneries receiving a subsidy from the taxes levied on Greek monasteries enjoying an annual income of over 100 ducats, the other one being the Latin Benedictine nunnery of Our Lady of Tyre. In December 1547, the Council of Ten decided to give a new annual subsidy to the nunnery of Pallouriotissa, amounting to eight ducats, so as to assist them in paying the tax levied on owners of livestock. Clearly, the nunnery must have been engaged in animal husbandry. Kyprianos, writing in the late eighteenth century, states that this nunnery, along with the monastery of St George of Mangana, was demolished in 1567 by the Venetians during the construction of the new circuit of walls for Nicosia (Mas Latrie, 1855, pp. 503-504; Lusignan, 1580, fols. 31r and 31v; Kyriazes, 1950, p. 108 no. 92 and pp. 130-131 no. 134; Aristeidou, 1993, pp. 199 and 201-202).

Turning to Greek churches and monasteries outside the capital, one notes that sometimes, the facilities were shared with Latin clergy. In 1483, the German Dominican friar Felix Faber remarked angrily during his visit to Cyprus on how a Greek monk habitually officiated in both the Latin and Greek chapels at the monastery of the Holy Cross at Stavrovouni, thereby deceiving the faithful of both the Latin and the Greek rites. The Czech pilgrim Oldrich Prefat observed in 1545 on his visit to Cyprus, that the Ayia Napa monastery church to the south of Famagusta was shared by Greek monks and Latin Augustinian canons. Greek monasteries in Cyprus were also in contact with Greek prelates from outside the island. The Hermitage founded by Neophytos the Recluse received a visit in 1523, during the period of Venetian dominion, from no less an exalted person than Patriarch Jeremiah I of Constantinople, who sojourned there for seventeen days (Mango \& Hawkins, 1966, pp. 129-130). Such contacts, however, could engender conflict. A letter of 15 October 1537 that the Venetian lieutenant on Cyprus addressed to the Council of Ten in Venice recounts how the Greek abbots of the Hermitage of St Neophytos and of the monastery of St Nicholas of Akrotiri had renounced their obedience to the Greek bishops of Cyprus and had sent monks to assume holy orders from either the Orthodox patriarch of Jerusalem or from that of Alexandria, whom they intended to recognise as their superiors (Aristeidou, 2003, no. 124).

Under the terms of the Bulla Cypria of 1260, this constituted an act of insubordination against the Greek bishops of Cyprus themselves, the papacy, the Latin archbishop and bishops of Cyprus, hence the lieutenant's concern. Indeed, had the abbots' plans been implemented, the monasteries would have become proprietary and come under the ius patronatus, leading to quarrels and controversies over patronal rights and jurisdiction. The abbots and all the monks who had been ordained by the patriarchs of Jerusalem and Alexandria were summoned before the lieutenant who decided to have the abbots removed from these monasteries and banned 
from their confines as unsuitable. The monks ordained by these patriarchs were sent before the vicar of the Latin diocesan bishop of Limassol, in accordance with customary procedure, and the lieutenant asked the Council of Ten to confirm his measures so that his successors would be able to punish any clergy falling into similar errors with greater facility (Aristeidou, 2003, no. 124). The final outcome of this matter is not known. The lieutenant's letter shows the determination of the Venetian authorities on Cyprus to uphold the authority of the papacy and the Latin church of Cyprus, but also how the Hermitage of St Neophytos maintained close contact with Orthodox institutions outside Cyprus even after three and a half centuries of Latin rule.

Venetian administrators were critical of Greek monastic life on Cyprus, as appears from their reports. The Councillor Fantino Dolfin observed in his report dated 4 June 1544 that the functioning Greek monastic houses on Cyprus numbering 27 were neither subject to visitations or reforms by any superior, on account of which many religious lived a worldly life, consuming incomes without providing any benefit to the Church. To introduce reforms, he suggested that the abbots be transferred every two years from one abbey to another, with the obligation to provide their successors with an inventory of all the abbey's fixed and movable properties, with a copy to be registered by the Venetian treasury, so that such abbots would not be able to take away anything other than their vestments. The outcome of this proposal is not known, but in his report dated 16 November 1553, the councillor Alvise da Ponte likewise cited the lack of supervision by suitable superiors as the reason for the moral turpitude of Greek abbeys Birdachas, 2019, pp. 147 and 180-181).

Despite such criticisms, Greek monastic life in Cyprus flourished under Venetian rule. Some years before the Turkish conquest, Bernard Sagredo, the Venetian general provveditor on Cyprus between 1562 and 1564, addressed a report dated 1562 to the Venetian Senate in which he observed that there were no less than 52 Greek monasteries throughout Cyprus, most of which were rich and devoutly attended. They came under the ius patronatus of the Venetian republic and therefore, on account of their proprietary status, could not elect abbots without the presence of Venetian officials. Those that had exiguous incomes received subsidies, in cash or kind, from the treasury of the Venetian government of Cyprus. The report of the Venetian councillor Bernardin Berlengo dated 15 September 1563 is slightly different. It states that whereas the houses of Latin monks, nuns and mendicants were impoverished, the Greek monasteries were mostly prosperous, but were around 35 in number, both in Nicosia and throughout the kingdom (Mas Latrie, 1855, pp. 540 and 543; Skoufari, 2011, p. 106; Birdachas, 2019, p. 261). 
It was decreed in 1544 that monasteries with an annual income of over 100 Venetian ducats should pay an eight per cent tax in order to subsidise the Greek monastery of Our Lady of Pallouriotissa near Nicosia, as well as the Latin monastery of Our Lady of Tyre in the capital. In 1547, an annual subvention of eight ducats was resolved for Our Lady of Pallouriotissa to enable it to pay the marzason, a tax levied on sheep and goats in the possession of free peasants, who in this instance must have been subject to the monastery. In 1549 corn, wine and sesame for the manufacture of candles were granted to the monastery of St Mammas of Morphou while in 1551, an annual subsidy of 25 ducats was decreed to support the impecunious monks of the monastery of St George Emphorites. A grant of wine was approved in 1553 for the monastery of Our Lady Acheiropoietos, while in 1554, 1558 and 1559 a grant of corn was decreed for the monasteries of Kykko, Andriou and St Nicholas tes Steges, respectively (Skoufari, 2011, pp. 106-107). Sagredo's number of Greek monasteries for the year 1562 was up nearly threefold from that of 18 given in Sylvester Minio's report of 1529 mentioned above. A considerable number of them, including some of the most important ones, were in and around Nicosia. Greek monastic life in the capital and elsewhere on Cyprus maintained a lively presence right up to the Ottoman conquest.

\section{REFERENCES}

\section{Primary Sources}

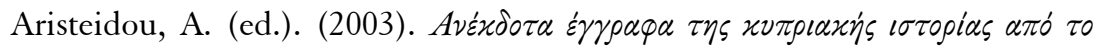

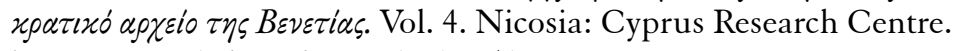

Beihammer, A. (ed. and trans.). (2007). Griechische briefe und urkunden aus dem Zypern der Kreuzfahrerheit: Die Formularsammlung eines königlichen sekretärs im Vaticanus Palatinus Graecus 367. Nicosia: Cyprus Research Centre.

Coureas, N. \& Schabel, C. (eds.). (1997). The Cartulary of the Cathedral of the Holy Wisdom of Nicosia. Nicosia: Cyprus Research Centre.

Coureas, N. (trans.). (2003). The Foundation Rules of Medieval Cypriot Monasteries: Makhairas and St. Neophytos. Nicosia: Cyprus Research Centre.

Coureas, N. (trans.). (2005). George Boustronios, A Narrative of the Chronicle of Cyprus 1456-1489. Nicosia: Cyprus Research Centre.

Dawkins, R.M. (ed. and trans.) (1932). Leontios Makhairas, Recital concerning the Sweet Land of Cyprus entitled "Chronicle". 2 vols. Oxford: Oxford University Press. 
Hofmann, G. (ed.). (1946). Epistolae Pontificae ad Concilium Florentinum Spectantes. Vol. 3. Rome: Pontificium Institutum Orientalium Studiorum.

Kezel, A.R. (trans.). (1990). Brigitta of Sweden, Life and Selected Revelations. New York: Paulist Press.

Lusignan, S. (1980). Description de toute l'isle de Cypre. Paris: Chez Guillaume Chaudiere

Maruhn, J. (ed.). (1981). Eine zyprische Fassung eherechtlicher Titel de Epitome. In D. Simon (ed.), Forschungen zur Byzantinischen Rechtsgeschichte, vol. VII, Fontes Minores IV. Frankfurt: Vittorio Klostermann.

Mas Latrie, L. de. (ed.). (1882). Documents nouveaux servant de preuves à l'histoire de l'île de Chypre sous le régne des princes de la maison de Lusignan. Collection des documents inédits sur l'Histoire de France, Mélanges historiques, IV. Paris: Imprimerie Nationale.

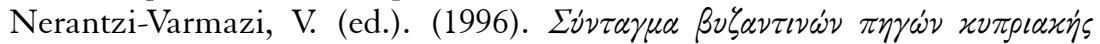

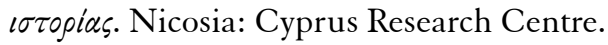

Richard, J. (ed.). (1983). Le livre des remembrances de la secrète du royaume de Chypre (1468-1469). Nicosia: Cyprus Research Centre.

Schabel, C. (ed.). (2001). The Synodicum Nicosiense and other Documents of the Latin Church of Cyprus. Nicosia: Cyprus Research Centre.

Schabel, C. (ed.). (2010). Papal Letters Concerning Cyprus 1196-1261. Nicosia: Cyprus Research Centre.

Simon, D. (ed.). (1973). Zyprische Prozessprogramme. Munich: Verlag C.H. Beck.

Smet, J. (ed.). (1954). The Life of St Peter Thomas by Philippe de Mézières. Rome: Institutum Carmelitanum.

\section{Secondary Sources}

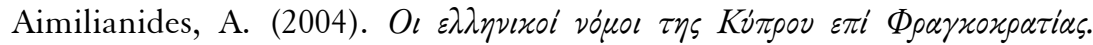

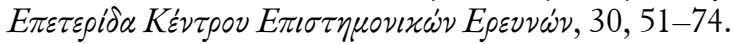

Angelomatos-Tsougaraki, H. (1995). Additions and Corrections to the Cod. Hierosol. Patriarch. 57: Its Links with Cyprus and Palestine. Byzantinische Forschungen, 21, 167-180.

Arbel, B. (2002). The Treasure of Ayios Symeon: A micro-historical analysis of colonial relations in Venetian-ruled Cyprus. Káutos: Cambridge Papers in Modern Greek, 10, 1-19.

Arbel, B. (2009). L'elezione dei prelati greci a Cipro durante la dominazione veneziana. In C. Maltezou, A. Tzavara, \& D. Vlassi. (eds.), I Greci durante la venetocrazia: Uomini, spazio, idée (XIII-XVIII sec.). Venice: Istituto ellenico di studi byzantini e postbizantini di Venezia, 373-380.

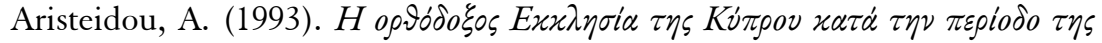

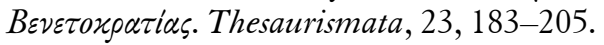




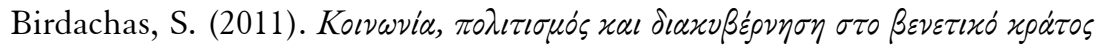

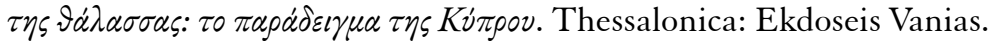

Coureas, N. (1996). The Orthodox Monastery of Mt Sinai and Papal Protection of its Cretan and Cypriot Properties. In M. Balard (ed.), Autour de la Première Croisade. Paris: Publications de la Sorbonne, 465-484.

Coureas, N. (1997). The Latin Church of Cyprus 1195-1312. Aldershot: Ashgate Publishing Ltd.

Coureas, N. (1998). Conversion on Latin Cyprus: A New Faith or a New

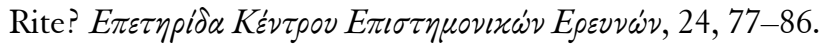

Coureas, N. (2010). The Latin Church in Cyprus 1313-1378. Nicosia: Cyprus Research Centre.

Coureas, N. (2012). A Political, Judicial and Ecclesiastical History of Nicosia. In D. Michaelides (ed.), Historic Nicosia. Nicosia: Rimal Publications, 121-136.

Coureas, N. (2019). The Syrian Melkites of the Lusignan Kingdom of Cyprus (1192-1474). Chronos, 40, 75-94.

Edbury, P. (1991, 19942). The Kingdom of Cyprus and the Crusades 1191-1374. Cambridge: Cambridge University Press.

Englezakis, B. (1995). Epiphanius of Salamis, the Father of the Cypriot Autocephaly. In idem, Studies on the History of the Church of Cyprus, 4th-20th Centuries. Aldershot: Ashgate Publishing Ltd., I, 29-40.

Grivaud, G. (2007). Les Lusignan patrons d' églises grecques. Byzantinische Forschungen, 39, 257-269.

Hackett, J. (1923). A History of the Orthodox Church of Cyprus, trans. K. Papaio-

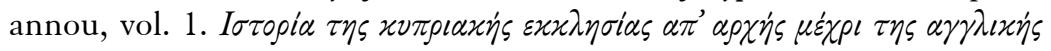

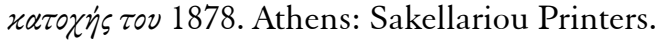

Herde, P. (2002). The Papacy and the Greek Church in Southern Italy between the Eleventh and the Thirteenth Century. In G.A. Loud \& A. Metcalfe (eds.), The Society of Norman Italy. Leiden: Koninklijke Brill NV.

Hill, G. (1948). A History of Cyprus: vol. 3. The Frankish Period 1432-1571. Cambridge: Cambridge University Press.

Kyriacou, C. (2018). Orthodox Cyprus under the Latins, 1191-1571. Lanham, Boulder, New York, London: Lexington Books.

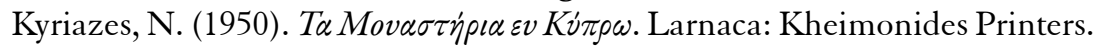

Mas Latrie, L. de (1855). Histoire de l'île de Chypre sous le règne des princes de la maison de Lusignan: vol. 3. Documents et mémoires. Paris: Imprimerie Impériale.

Mango C. \& Hawkins E.J.W. (1966). The Hermitage of St Neophytos and its Wall Paintings. Dumbarton Oaks Papers, 20, 119-206.

Mc Kee, S. (2000). Uncommon Dominion: Venetian Crete and the Myth of Ethnic Purity. Philadelphia: University of Pennsylvania Press.

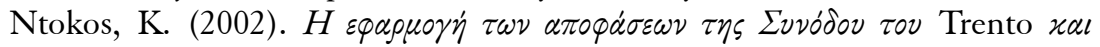

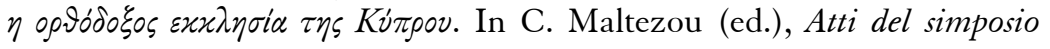


internazionale Cipro-Venezia, comuni sorti storiche. Venice: Istituto ellenico di studi byzantini e postbizantini di Venezia, 209-216.

Olympios, M. (2018), Building the Sacred in a Crusader Kingdom: Gothic Church Architecture in Lusignan Cyprus, c. 1209 - c. 1373. Turnhout: Brepols Publishers.

Richard, J. (1986). Un monastère grec du Palestine et son domaine chypriote.

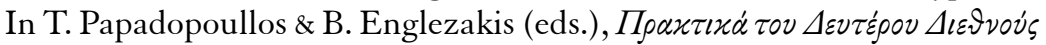

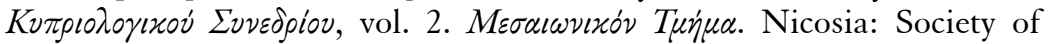
Cypriot Studies, 61-75.

Richard, J. (1992). Culture franque et culture grecque dans les royaumes d'Arménie et de Chypre au XVème siècle. In idem, Croisades et Etats Latins d'Orient. Aldershot: Ashgate Publishing Ltd., XVIII, 399-415).

Rudt de Collenberg, W. (1982/2). Le royaume et l'église de Chypre face au Grand Schisme (1378-1417), d'après les registres des archives du Vatican. Mélanges de l'École française de Rome, 94, 621-701.

Schabel, C. (2010a). Martyrs and heretics, intolerance of intolerance: the execution of thirteen monks in Cyprus in 1231. In idem, Greeks, Latin and the Church in Early Frankish Cyprus. Farnham: Ashgate Publishing Ltd., III, $1-33$.

Schabel, C. (2010b). The Greek Bishops of Cyprus, 1260-1340, and the Synodikon Kyprion. In idem, Greeks, Latin and the Church in Early Frankish Cyprus. Farnham: Ashgate Publishing Ltd., IV, 217-234.

Schabel, C. (2012). Ecclesiastical Monuments and Topography. In D. Michaelides (ed.), Historic Nicosia. Nicosia: Rimal Publications, 152-198.

Skoufari, E. (2011). Cipro Veneziana (1473-1571) Istituzioni e culture nel regno della Serenissima. Rome: Viella.

Skoufari, E. (2012). L'arcivescovo Filippo Mocenigo e l'applicazione della riforma Tridentina a Cipro. In B. Arbel, E. Chayes \& H. Hendrix (eds.), Cyprus and the Renaissance (1450-1650). Turnhout: Brepols Publishers, 205-230.

Tsirpanlis, Z. (1972). Memorie storiche sulle comunità e chiese greche in Terra d'Otranto (XVI sec.). In M. Maccarone, G.G. Meersseman, E. Passerin d' Entrèves, \& P. Sambin (eds.), La Chiesa greca in Italia dall' VIII at XVI secolo, vol. 2. Padua: Editrice Antenore, 845-877.

Voisin, L. (2013a). Francs de Chypre et monastères grecques: Le jus patronatus en question. Cahiers du Centre d'Études chypriotes 43, 393-404.

Voisin, L. (2013b). L'Église de Chypre dans les années 1460-1480 d'après la correspondence de Benedetto Soranzo. Thesaurismata 43, 93-114.

Nicholas Coureas - Senior Researcher at the Cyprus Research Centre in Nicosia on the history of Lusignan Cyprus (1191-1473). Within this field, his special interests are the history of the Latin Church of Cyprus and of 
Cypriot commerce during the Lusignan period. He has published various articles and books on this subject, including the monograph, The Latin Church in Cyprus 1195-1312 and its sequel, The Latin Church of Cyprus 1313-1378. Together with Michael Walsh and Peter Edbury, he published the conference proceedings: Medieval and Renaissance Famagusta. Together with Prof. Peter Edbury he also published the Italian translation of The Chronicle of Amadi. He has now completed a monograph, titled The Burgesses of Lusignan Cyprus 1192-1474. This will be published in 2020 by the Cyprus Research Centre. 
